\title{
Developing a User Friendly Decision Tool for Agricultural Land Use Allocation at a Regional Scale
}

\author{
Sumbangan Baja ${ }^{1}$, Samsu Arif ${ }^{2} \&$ Risma Neswati ${ }^{1}$ \\ ${ }^{1}$ Department of Soil Science, Hasanuddin University, Makassar, Indonesia \\ ${ }^{2}$ Department of Physics, Hasanuddin University, Makassar, Indonesia \\ Correspondence: Sumbangan Baja, Department of Soil Science, Hasanuddin University, Makassar, Indonesia \\ 90245; Tel/Fax: 62-411-587-076, 62-411-586-016/62-411-586-588. E-mail: sbja02@yahoo.com.au, \\ samsu_arif@yahoo.co.id, neswati76@gmail.com
}

Received: January 4, 2017

Accepted: February 25, 2017

Online Published: April 8, 2017

doi:10.5539/mas.v11n5p11

URL: https://doi.org/10.5539/mas.v11n5p11

\begin{abstract}
Agricultural land use planning should always be guided by a reliable tool to ensure effective decision making in the allocation of land use and activities. The primary aim of this study is to develop a user friendly system on a spatial basis for agricultural land suitability evaluation of four groups of agriculture commodities, including food crops, horticultural crops, perennial (plantation) crops, grazing, and tambak (fish ponds) to guide land use planning. The procedure used is as follows: (i) conducting soil survey based on generated land mapping units; (ii) developing soil database in GIS; and (iii) designing a user friendly system. The data bases of the study were derived from satellite imagery, digital topographic map, soil characteristics at reconnaissance scale, as well as climate data. Land suitability evaluation in this study uses the FAO method. The study produces a spatial based decision support tool called SUFIG-Wilkom that can give decision makers sets of information interactively for land use allocation purposes. This user friendly system is also amenable to various operations in a vector GIS, so that the system may accommodate possible additional assessment of other land use types.
\end{abstract}

Keywords: agricultural land use, GIS, land suitability evaluation, decision support, SUFIG-Wilkom

\section{Introduction}

Land use planning in agricultural development is necessary to guide decision makers in attempting to select appropriate types of land use, determining optimal spatial locations of the planned agricultural activity, identifying and formulating opportunities for land use change, and anticipating the consequences of changing land use policies. As a core component of land use planning, land suitability assessment is fundamental at all stages of planning and implementation, and at any stage of development of an area (Nurmiaty \& Baja, 2014) to determine the suitability and availability of land for alternative uses.

In Indonesia, agricultural development has gradually shifted to using marginal land as agricultural land is undergoing a massive transformation. This is often accompanied by changing objectives of land use, owing to increasing demands for specific commodities in the rural environment. Such a practice threatens long-term ecologically sustainable production which is recognized as a key element of food security, particularly in resource-poor areas. Moreover, land use change from agriculture to non-agriculture as such becomes one of common phenomena in urban and rural areas that threaten the country's food security program.

Therefore, a tool needs to be developed to assist land resource assessment in the decision making of land use choices for a dual and indivisible role: the first being that of maximizing benefits (productivity of the land), and the other being that of managing public goods: the environment (see Baja, 2009). To achieve this, it requires an effective management of geospatial information on the land on which such decisions should be based. Land suitability evaluation, as one of the branches of land resource evaluation (FAO, 1976) or land resource assessment, has been recognized among land use planners and policy makers as a primary tool for making appropriate land use choices (see Baja, 2009; Elsheikh et al., 2013).

From land resource assessment perspectives, collection of information over space and time has always outperformed our ability to interpret and apply the data. Consequently, the major goal of land suitability evaluation for site-specific management, which is to see a continuous improvement of management decisions, 
has lagged as a result of poor agronomic interpretation and information delivery (Cook \& Bramley, 2001). Engineers, soil scientists, agronomists, and geo-spatial analysts must together develop frameworks to maximize the flow of information back to farm managers to improve land management.

Nowadays, user friendly system in form of decision support system (DSS) has become one of important tools in land use planning and management (Demetriou et al., 2012; Sugumaran, 2011), and specifically, has created opportunities for providing information on site-specific land management through the collection and synthesis of land resources and production data in the fields (Aubert et al., 2012). The primary aim of this study is to develop a user friendly system for assessing land suitability for agricultural development using Geographic Information Systems (GIS). The framework developed will lead to better interpretation of precision land management in the study area. In South Sulawesi, Indonesia, such tool is required to enable integrating existing geospatial information in a form that is amenable to various procedures in decision making processes in management of agricultural land.

\section{Materials and Methods}

\subsection{Study Area}

The study area selected for the application of this user friendly system is Jeneponto District. It is located about $90 \mathrm{~km}$ southwest of Makassar, the capital of South Sulawesi Province (Figure 1 and Figure 2). This district consists of eleven sub-districts, with a total area of approximately 79.000 ha (BPS Kabupaten Jeneponto, 2013). This region is recognized as one of the areas with the driest climate regimes in South Sulawesi. Due to a lack of water availability, the predominant land use in this area is dry land agriculture, with the main crops are maize and rainfed rice. Maize (local variety) has long been recognized as the main commodity in this region.

\subsection{The Database}

The user friendly system developed in this study utilizes data sets from the following sources: (i) digital topographic map; (ii) soil map and soil characteristics; (ii) climate data; and (iii) LANDSAT imagery. Some additional supporting data include administration boundary at a sub-district level (Indonesian: kecamatan), geology, contours, catchment boundary, land use/land cover.

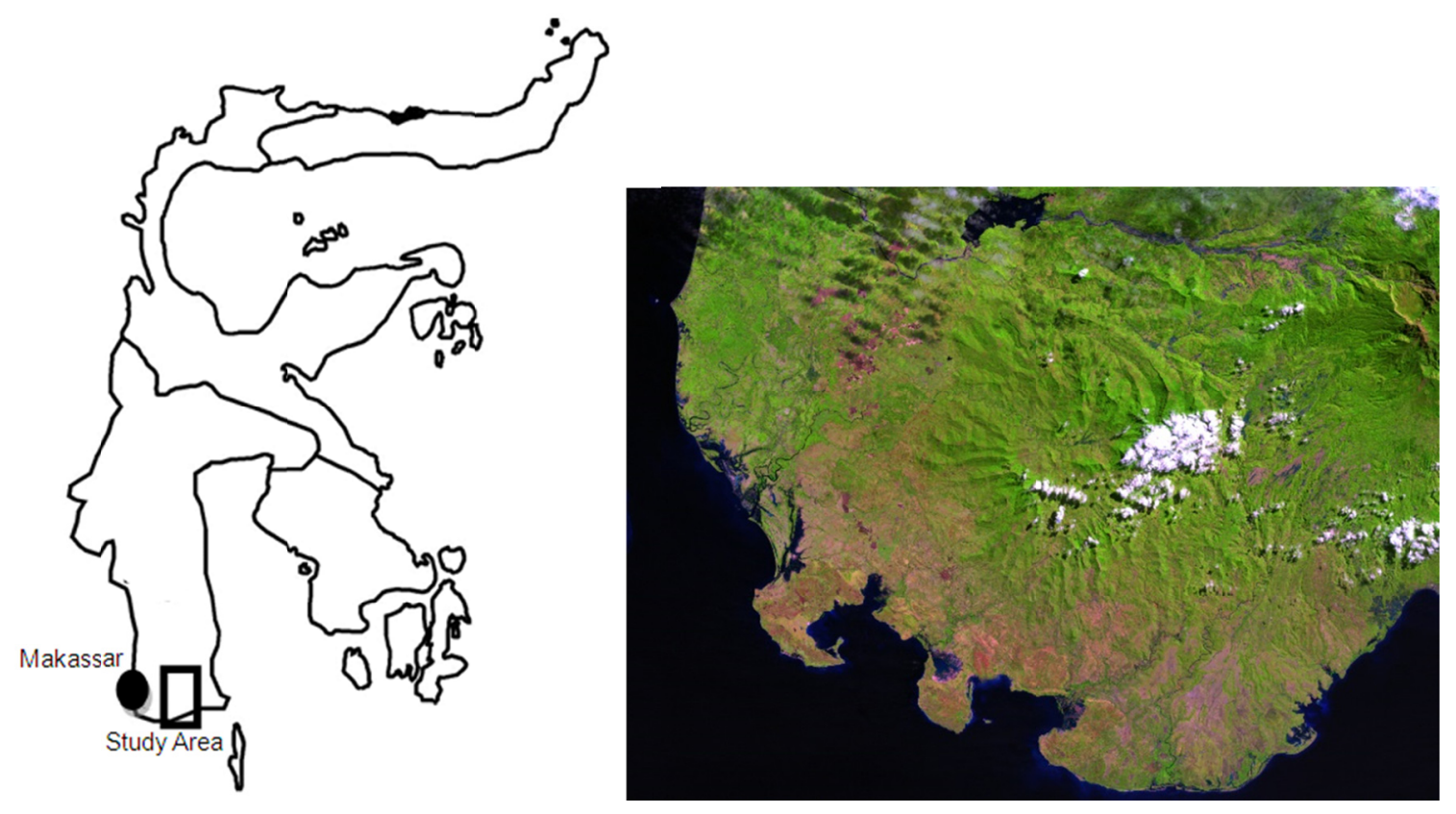

Figure 1. Study area at Sulawesi Island (left) and Landsat image showing the location of project site 


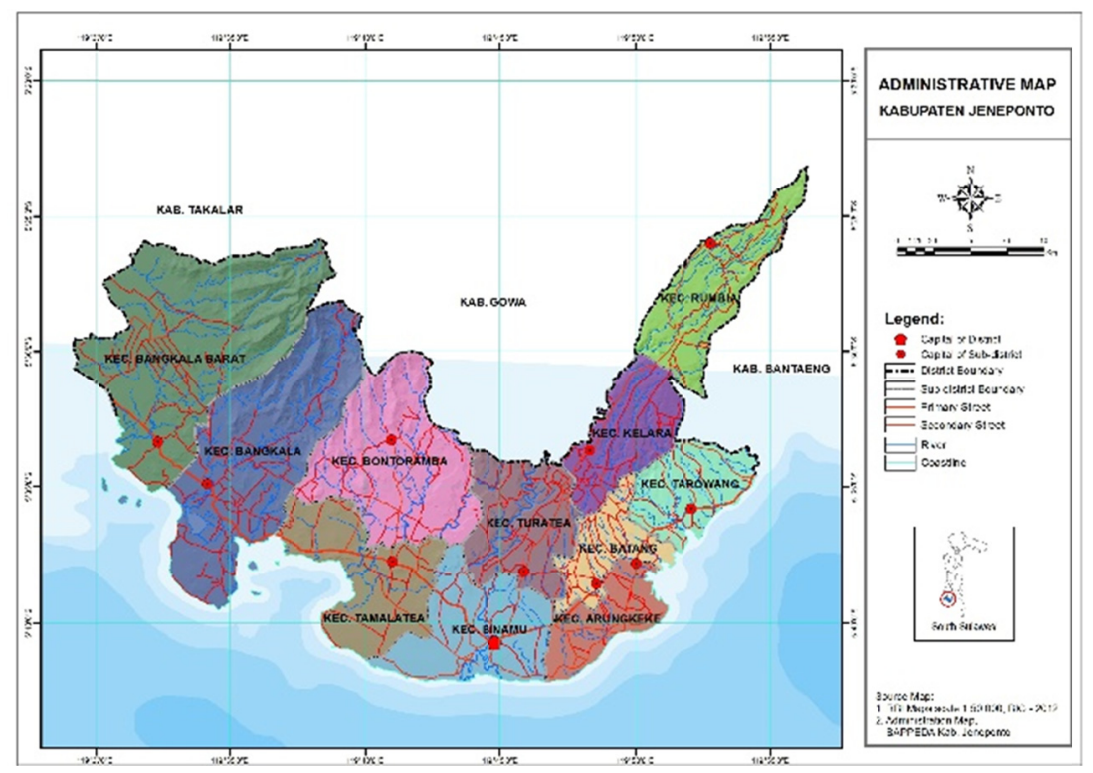

Figure 2. Administration boundary of study area

Digital topographic maps of study area with a scale of $1: 50,000$ from BIG (National Agency for Geospatial Information) were used as a reference for mapping. The digital topographic maps were available in a vector GIS format, makes it easier to build data bases in a standard vector GIS. All the data layers were stored using UTM (Universal Transverse Mercator) coordinate system. As the area of interest covers three sheets of topographic maps, then a process of joining all the elements of map layer was undertaken, before defining the boundary of study area. The main data layers used include contour lines ( 25 meter interval), rivers and streams, roads (main, secondary, and tertiary), and residential sites.

In this study, the main reference for soil data layers is land systems map developed by Regional Physical Planning Project for Transmigration (RePPProT, 1988) at a reconnaissance scale (Figure 3). However, with a GIS technique further division of land mapping units (based on topography, land use, and geology) was undertaken to provide a basis for field survey and sampling procedures in the field.

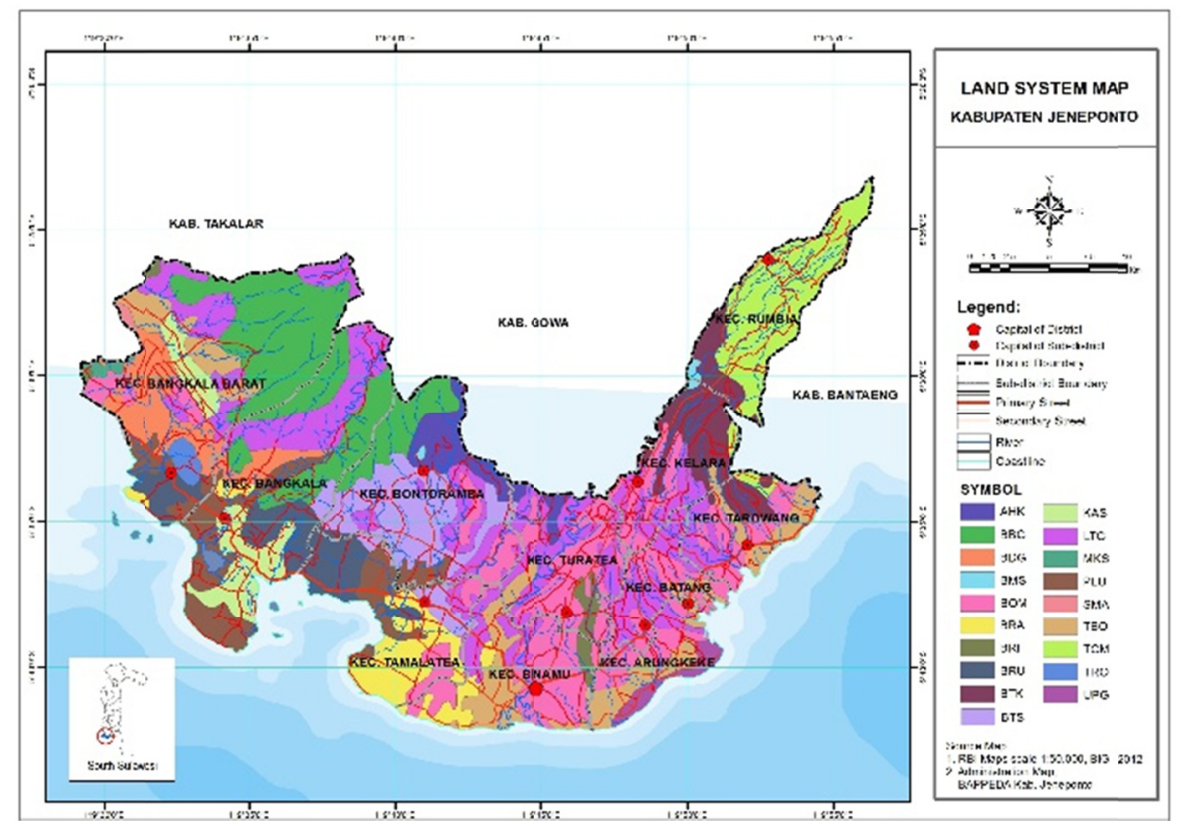

Figure 3. Land systems of study area (note: the symbols in the legend signify local name of land systems, at a reconnaissance scale) 


\subsection{Land Suitability Evaluation Method}

Land evaluation procedures in this study involve eight main components (Figure 4). The assessment of land quality for a specific type of land use should be based on land use requirements and constraints. Such requirements and constraints are then used as the basis for establishing what is termed evaluation criteria or decision criteria. This is then considered as a multicriteria decision making analysis (Sarkar et al., 2016). With reference to these decision criteria, a set of algorithms is then employed to match the existing quality of land and the requirements of that particular type of land use. The matching procedure then gives rise to a ranking of the potential of land for a given purpose (Nurmiaty \& Baja, 2014), whether categorical or continuous grades. Regardless of the approaches employed, the final result of land evaluation is a map that portrays the divisions of the area of interest into suitability classes or indices of land units for a nominated land use.

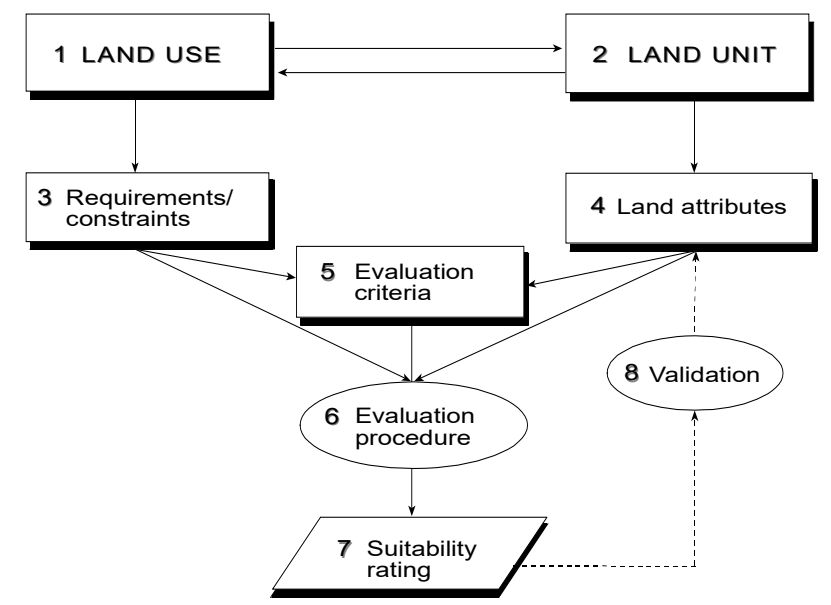

Figure 4. Components of land suitability evaluation in this study

Database of the system contains various commands for depicting land suitability class in the study region. Land suitability classification in this study was undertaken based on the framework for land evaluation guidelines of FAO (1976). The classification is purely based on inherent land characteristics, which is popular among soil scientists and agronomists, where the main concern is classifying the land according to the goodness or appropriateness of soil characteristics for a specific purpose (see for example Baja et al., 2014; Davidson et al., 1994). As seen in CSR/FAO (1983), the FAO's land suitability scheme is divided into Order, Class, Sub Class, and Unit. Order is the global land suitability group, and is divided into S (Suitable) and N (Not Suitable). Class is the land suitability group within the Order level. Land suitability classification is undertaken based on the level of detail of the data available. For example, at a semi detailed mapping activity the $\mathrm{S}$ order is divided into Highly Suitable (S1), Moderately Suitable (S2), and Marginally Suitable (S3). In the "Not Suitable" order no further division is made.

Furthermore, Sub-Class is indicated by the type and level or degree of limitations in each division. For example, land unit having a limiting factor of rooting condition at a marginal level is indicated by a Subclass S3rc. Further, detailed divisions of Sub-Classes into Units can be made according to differentiation in soil effective depths. The effective depths of $50-70 \mathrm{~cm}$ and $<50 \mathrm{~cm}$, are respectively classified as $\mathrm{S} 3 \mathrm{rc} 1$ and $\mathrm{S} 3 \mathrm{rc} 2$ (Djaenuddin et al., 2003).

\subsection{Land Units And Soil Characteristics}

Soil characteristics surveyed and analysed for developing the SUFIG-Wilkom system include those forming the basic criteria for land suitability classification according to FAO (1976) (Table 1). The data on climate such as average temperature, rainfall, number of dry months were obtained from local meteorological station.

Table 1. Land qualities and land characteristics observed in the study area (CSR/FAO, 1983)

\begin{tabular}{ll}
\hline Land Qualities & Land Characteristics \\
\hline Temperature (tc) & Average temperature $\left({ }^{\circ} \mathrm{C}\right)$ \\
Water availability (wa) & Rainfall (mm), moisture (\%), Number of dry months \\
Oxygen availability (oa) & Drainage \\
\hline
\end{tabular}




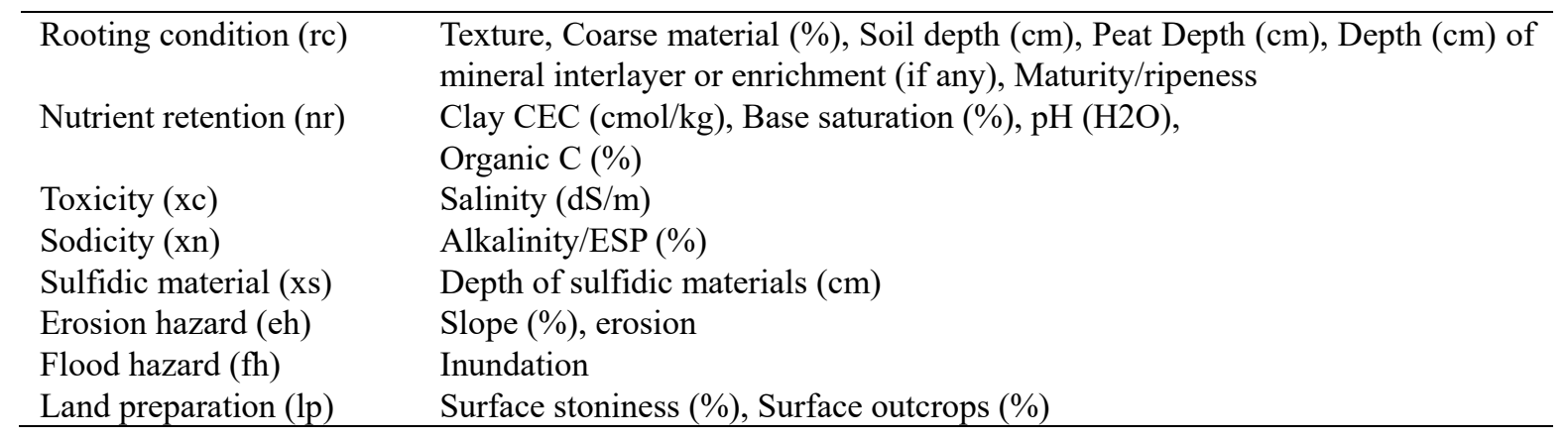

\section{Results and Discussions}

\subsection{GIS Database Processing}

In this project, data processing and spatial analysis were undertaken in a vector GIS, on the basis of different themes developed earlier in system development. A GIS database table containing the names and codes of all unique attributes in the study area was constructed in a relational database system. As seen in a common GIS data base, unique soil identification numbers (IDs) were assigned to each record, and fields were added to indicate map unit types and a general classification of soil type at a sub-group level. Relationships between the various data sources as mentioned above were defined and well organized in a system (GIS and its derived subsystem SUFIG-Wilkom). At each stage of database processing, careful consideration was given when designing a spatially referenced soils database to ensure database table linkages, due to the nature of soil mapping units, taxonomic classifications (USDA, 2006), and the taxonomic level at which the soils were mapped, and the level at which soil attribute data was recorded. It also applies to other GIS data layers and attributes.

In terms of land suitability classification, SUFIG-Wilkom contains interactive commands that has a linkage to database of land and requirements of crops. In GIS systems, all these data sets provide a complex set of relationships between soil profile attribute data (i.e., characteristics as shown in Table 1), soil type, and soil mapping unit, so that the flow of soil profile data from the soil attribute tables to linkage with the database tables of the digital soil maps can be well understood. The tables are arranged such that all relationships are "one-to-many," thereby facilitating data flow and database queries in GIS (Baja, 2009). GIS database consists of two sets: spatial data and attribute information attached to spatial data.

\subsection{Programming Tools}

SUFIG-Wilkom is constructed by utilizing a programming tools that allow for customizing the existing application programs in GIS. With such tools, the capability and functionality of SUFIG-Wilkom can be improved considerably or even expanded up better than the standard package modules (see for examples, Andreu et al., 1996; Oliver et al., 2012). All the functionality contained in SUFIG-Wilkom can be controlled by a program that is created using the Visual Basic programming tools. Visual Basic is a system that is more powerful and more compatible with other applications including ArcObject features that allow for creation of a stand-alone application.

\subsubsection{Menu and Toolbar}

Menu is a list of commands that is found at the top of SUFIG-Wilkom, while toolbar is a set of tools that are grouped according to their respective functions. This study utilises four main menus that are prepared for use in current research or future development. These main menus consist of (Figure 5):

- Commodity_Selection

- Land_Characteristics

-Economic_Analysis

- Spatial_Analysis 


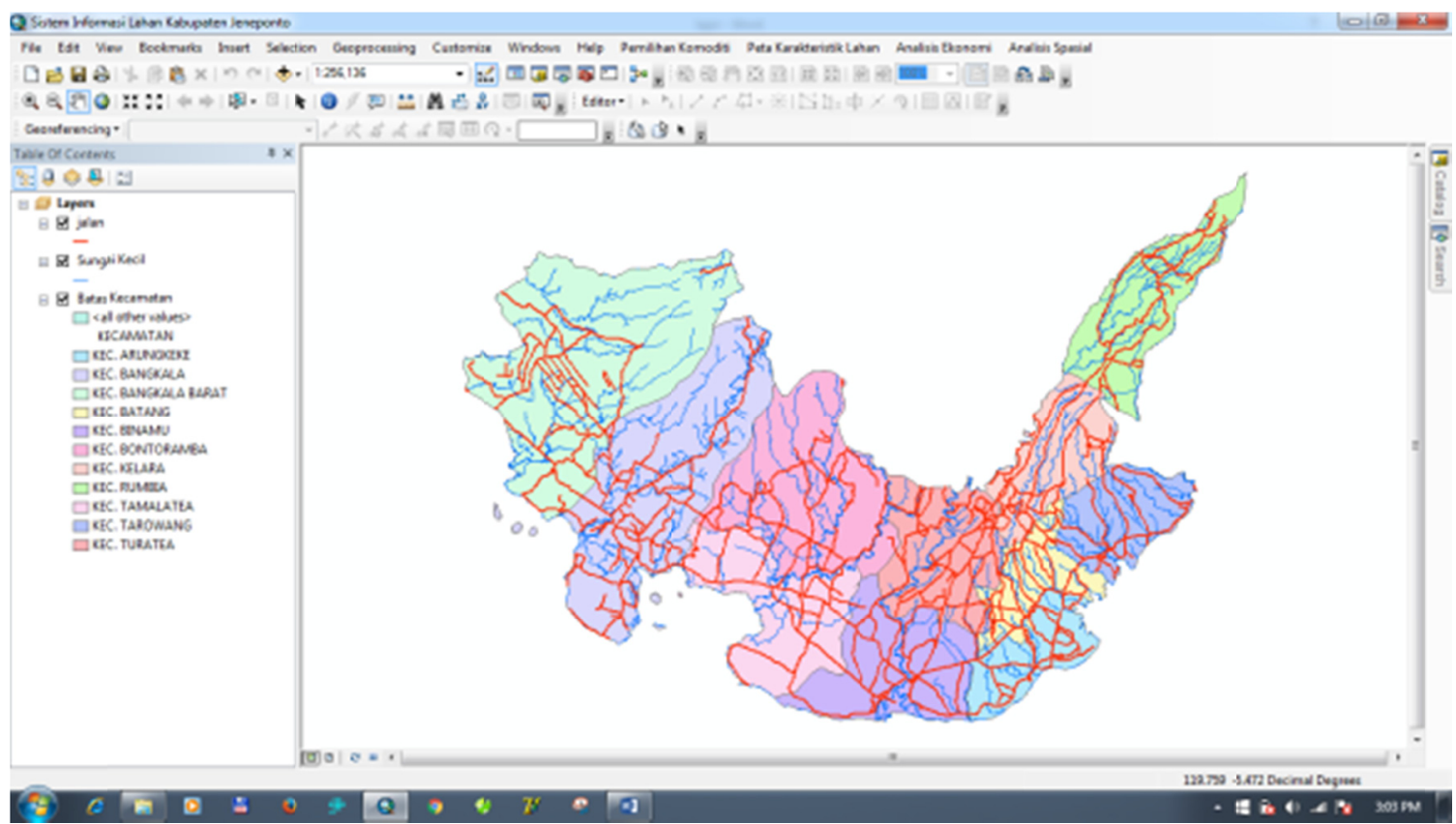

Figure 5. The main menu on SUFIG-Wilkom

Commodity_Selection menu consists of six sub-menus, where the division is based on the grouping of plants and area calculation tool of land suitability classes. The six submenus are as follows (Figure 6):

- Food_Crops

- Horticultural_Crops

- Plantation_Crops

- Grazing

- Tambak (Fish Ponds)

- Land_Suitability_Class_Area

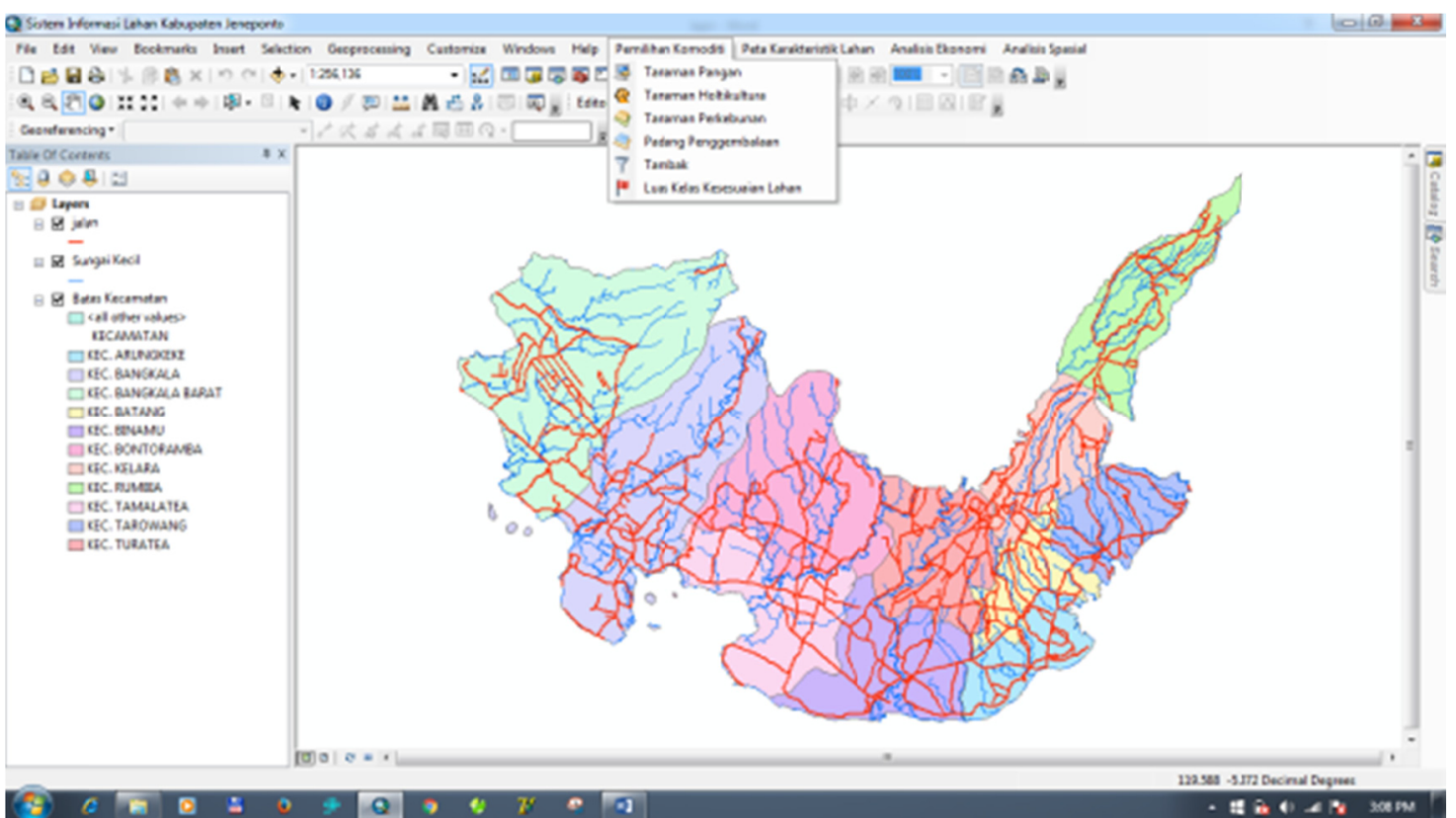

Figure 6. Submenu for Commodity_Selection 
The menu for Land_Characteristics consists three submenus, namely Base_Map, Thematic_Map, and Soil_Characteristic_Map. Each submenu contains map layers (spatial data) accompanied by attribute information that can be accessed interactively within the system (Han et al., 2012).

Toolbar available in this system consists of three buttons which are grouped in the SIL-Jeneponto group $=: \frac{2}{2}+=$

The first button is used to display land suitability class and area (in ha) of each polygon clicked or pointed. The second button is used to show the economic feasibility (still in development), whereas the third button is featuring limiting factors on land suitability classes except for land with class S1, where no significant limitation exists.

\subsubsection{Forms}

A form is used for enabling the system to create a GUI (Graphical User Interface) as a medium to interact with the user. A form contains the components and control as needed. Form is designed to enable users to interact with the system, or commonly referred to as user friendly. In this system, there are two forms that have been developed, i.e., form for Food Crops, consisting of two pieces of control, namely ComboBox and Button. ComboBox gives users the option to choose type of crops, such as Irrigated Rice, Rainfed Rice, Corn, Soybeans, Peanuts, Green Beans, Cassava and Sweet Potato. Controls in the form Button is used to execute the selection in the ComboBox control. Menus developed at this stage are as follows:

- Form for Land Suitability Class presents commodity names, land suitability classes, and area of each land suitability classes.

- Form for Thematic Map has a choice in the ComboBox for various types of thematic maps, including climate land cover, slope, geological, forest status, watershed, and land system.

- Form for Land Characteristics Map, has a choice in the ComboBox for various types of soil characteristics maps, such as: texture, content of nitrogen, rock types, organic $\mathrm{C}$ content, $\mathrm{CEC}$, soil $\mathrm{pH}$, salinity, bulk density, phosphor, potassium, hydraulic conductivity.

Apart from the above mentioned forms there are two other forms will be developed in the next stage of this study, namely: Economic Analysis (see Walpole, 1998), and Spatial Analysis. Due to its flexibility, the system may also expanded to other required tools (Meensel et al., 2012; Eastwood et al., 2012).

\subsection{How SUFIG-Wilkom Works}

SUFIG-Wilkom application works on a standalone platform, so by double-clicking the shortcut of SUFIG-Wilkom on the desktop screen, it will display the main page as shown in Figure 7.

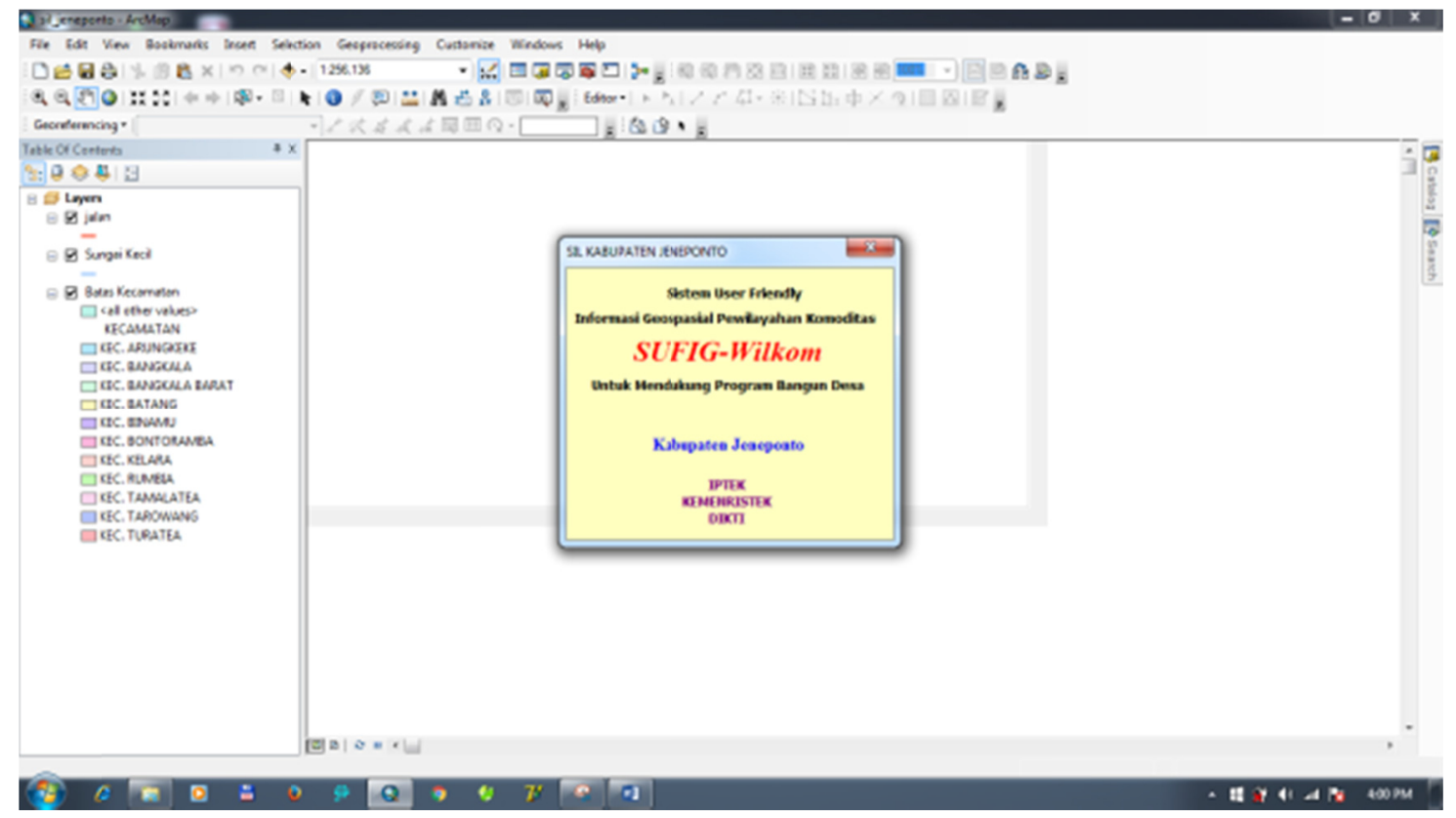

Figure 7. Main page of SUFIG-Wilkom 
If the splash form is closed, the application system will automatically call the three layers shown in the map area, namely Roads, Rivers and the District Boundaries in the district of Jeneponto. In addition to displaying a base map of the area map, menus and forms attached to each sub menu are ready for use, including a toolbar that has been made at the time of system design. Here are some examples showing how the system works.

\subsubsection{Displaying Commodity_Selection Options Menu}

If the Commodity_Selection menu is selected, and then select a sub menu Food_Crop, then the system will open the form selection of crops. When choosing one type of food crops like Irrigated Rice, the system will automatically display the map of land suitability for Irrigated Rice, as shown in Figure 8. The polygons are displayed based land suitability classes. For S1 class (suitable) displays green, the S2 class (moderately suitable) depicts blue, S3 class (marginally suitable) is represented by yellow colour, and N class (not suitable) as red. The color may be changed according to user's preferences. To account for area of each land suitability class, then the user selects a sub menu Land_Suitability_Class_Area. Selection of other crop types may be done in the same way; every land suitability maps can be displayed automatically based on the options that exist in the Food_Crops form.

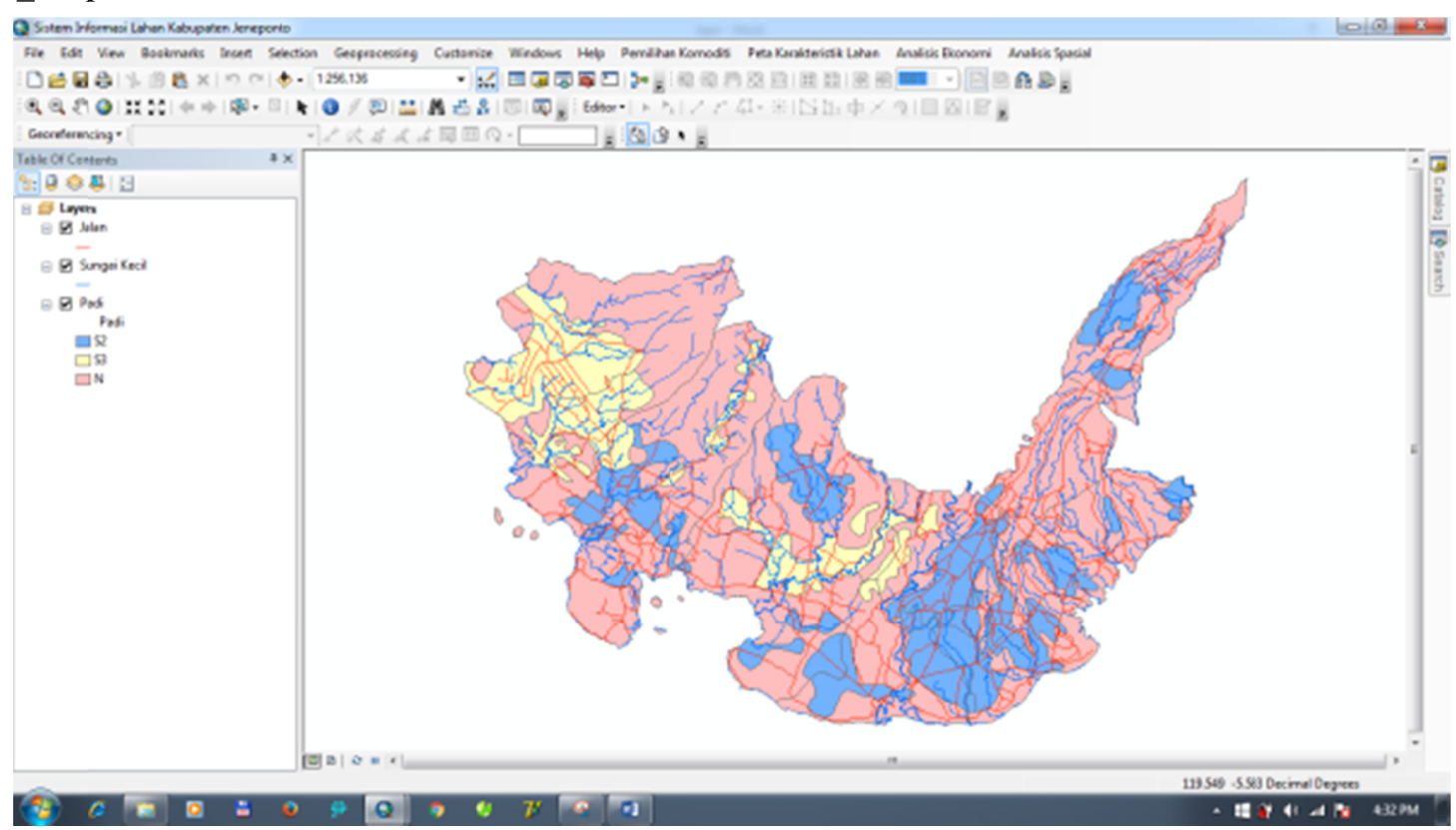

Figure 8. Land suitability layer for Irrigated Rice

\subsubsection{Displaying Menu for Land Characteristics}

Menu for Land Characteristics Map consists of three sub-menus as described on the design of the menu and toolbar, as follow: (i) sub-menu for base maps; (ii) sub-menu for thematic maps; and (iii) sub-menu for land characteristics map. Each sub-menu contains attribute information, which is amenable to various operations and map queries (see also Elsheikh, 2013; Han et al., 2012, Oliver et al., 2016).

\subsubsection{Supporting Components}

SUFIG-Wilkom application system works on the ArcGIS platform so that all facilities owned by ArcGIS can be used on the system, such as:

- Menu Bar Standard, is a collection of menus that are owned in ArcMap.

- Table of Contents (TOC), can be regarded as content data contained in the Map Area. TOC consists of a frame that contains layers that represent the data. Some actions that can be performed by the TOC are: (i) Set the composition of the layers that exist in Area Map; (ii) defines property as a symbol of spatial data, query, transparency, labeling international based on the attributes etc.; (iii) View the coordinate system used; (iv) Open the attribute table of spatial data.

- Toolbox is a collection of tools that are provided to carry out certain operations. Toolbox can be activated by clicking the icon on the Toolbar menu standard of ArcToolbox.

- Folder Area (work area), is an area that shows the existing spatial data. 
- Map coordinates, like other GIS software, ArcMap has a facility that can show map coordinates dynamically based on the movement of the mouse. It is located on the lower left side of the work area.

- Data Exploration uses the Zoom In button, to enlarge the desired area of the work area. This is done by pressing the left mouse button then form a grid and then release the left mouse button to enlarge the view. Use the Pan button to move the map is in the work area. Press the mouse and then drag the desired direction, then release the mouse button. Click the Full Extent button to display the map as a whole.

\subsection{System and Map Products}

The outputs of SUFIG-Wilkom are two-folds. First is the system itself, that can help users in decision making processes. Second is map products. Map product may be composed using layout formats according to user's preferences. From the available map layers, users may also create various statistics forms for presentation, such as tables, diagrams, graphs extracted from contents of GIS database of corresponding map layers. For Land_Characteristics sub-menu, for examples, it may be displayed by each type of land characteristics, or by overall land suitability level for a specific crop. For instance, soil acidity information in the study area is presented in Figure 9, and its attribute information may be extracted from spatial data at various forms.

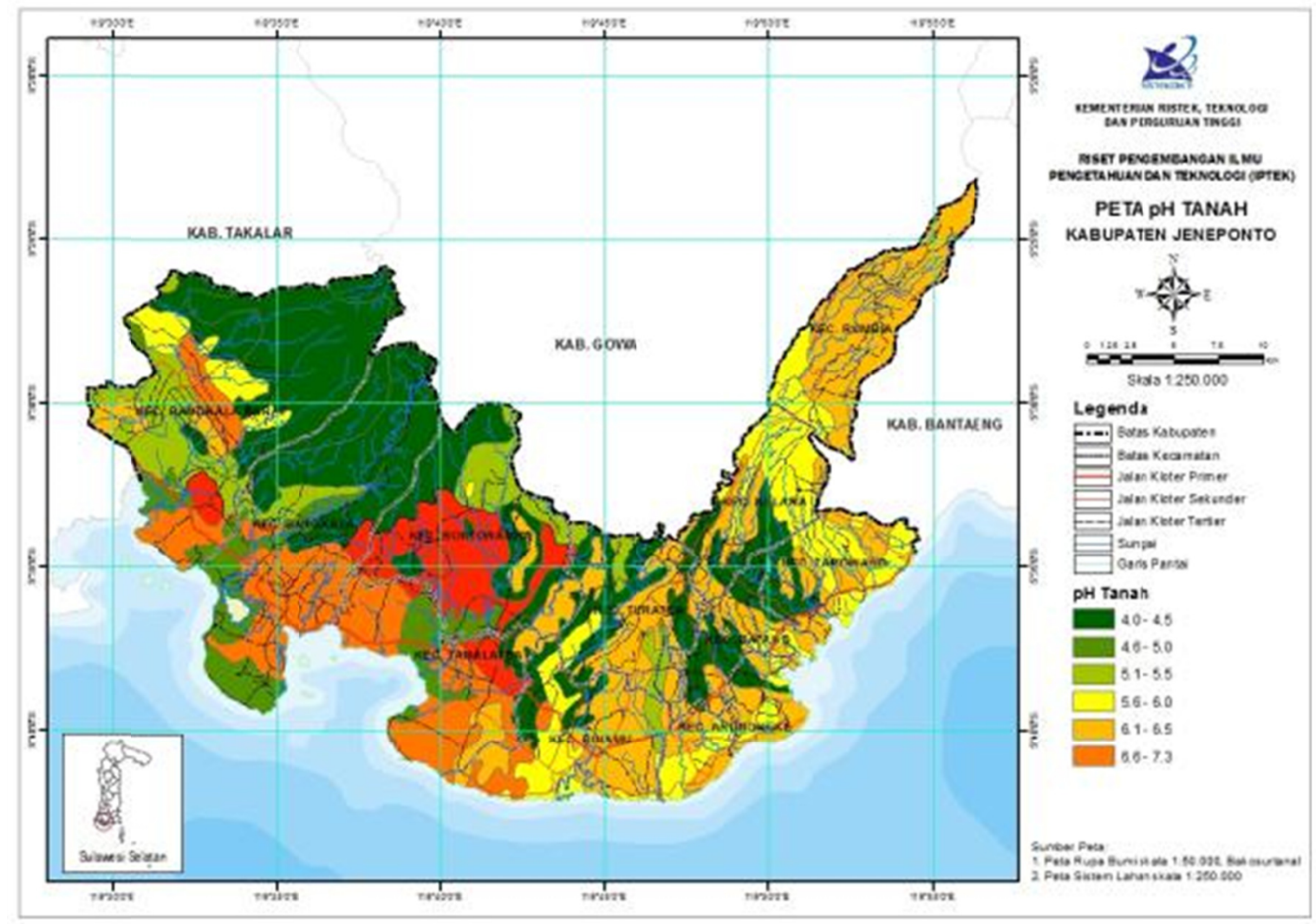

Figure 9. Distribution of Top soil $\mathrm{pH}$ in the study area

\section{Conclusion}

This study has produced a user friendly system that can be used for optimal decision making in land use (agricultural commodity) allocation, on the basis of land suitability assessment. The SUFIG-Wilkom system runs interactively in GIS to guide users to understand the study area, especially land characteristics, associated information related to land use, and the suitability of area to selected crop types. The system facilitates four groups of agriculture commodities, including food crops, horticultural crops, perennial (plantation) crops, grazing, and fish pond (tambak). The system is amenable to various updating mechanisms to facilitate more parameters and criteria, as well as more attribute data to enable optimal decision may be made at different scales of assessment. A user friendly system based on GIS demonstrated in this study can accommodate information sets at different level of detail, from reconnaissance scale to detailed mapping where the spatial data are available with a good mapping accuracy. 


\section{Acknowledgement}

The authors would like to thank farmers in Jeneponto District for giving excellent response to our research team. Financial support provided by the Directorate of Higher Education, Ministry of National Education, Republic of Indonesia (now Ministry of Research, Technology, and Higher Education) through a competitive based research: HIBAH PENERAPAN IPTEK Batch I and II is greatly appreciated.

\section{References}

Andreu, J., Capilla, J., \& Sanchís, E. (1996). AQUATOOL, a generalized decision-support system for water-resources planning and operational management. Journal of Hydrology, 177(3), 269-291.

Aubert, B. A., Schroeder, A., \& Grimaudo, J. (2012). IT as enabler of sustainable farming: An empirical analysis of farmers' adoption decision of precision agriculture technology. Decision Support Systems, 54(1), $510-520$.

Baja, S. (2009). Land use choice and land resource assessment in agriculture. CAB Reviews: Perspectives in Agriculture, Veterinary Science, Nutrition and Natural Resources, 4(15), 1-5.

Baja, S., Nurmiaty, \& Arif, S. (2014). GIS-based soil erosion modeling for assessing land suitability in the urban watershed of Tallo river, South Sulawesi, Indonesia. Modern Applied Science, 8(4), 50-56. https://doi.org/10.5539/mas.v8n4p50.

BPS Kabupaten Jeneponto. (2013). Kabupaten Jeneponto Dalam Angka. Pemerintah Kabupaten Jeneponto, Bontosunggu.

Cook, S. E., \& Bramley, R. G. V. (2001). Is agronomy being left behind by precision agriculture? In Proceedings of the 10th Australian Agronomy Conference, Hobart, 28 January -1 February. (ASA: Hobart.)

CSR/FAO. (1983). Reconnaissance Land Resources Surveys 1 : 250,000 Atlas Format Procedures. Centre for Soil Research (CSR) Republic of Indonesia, Bogor.

Davidson, D. A., Theocharopoulos, S. P., \& Bloksma, R. J. (1994). A land evaluation project in Greece using GIS and based on Boolean and fuzzy set methodologies. International Journal of Geographic Information Systems, 8, 369-384.

Demetriou, D., Stillwell, J., \& See, L. (2012). Land consolidation in Cyprus: Why is an Integrated Planning and Decision Support System required? Land Use Policy, 29(1), 131-142.

Djaenuddin, D., Marwan, H., Subagjo, H., \& dan Hidayat, A. (2003). Petunjuk Teknis Evaluasi Lahan untuk Komoditas Pertanian. Versi 3. Balai Penelitian Tanah, Puslitbang Tanah dan Agroklimat, Bogor.

Eastwood, C. R., Chapman, D. F., \& Paine, M. S. (2012). Networks of practice for co-construction of agricultural decision support systems: Case studies of precision dairy farms in Australia. Agricultural Systems, 108(4), 10-18.

Elsheikh, R., Shariff, A. R. B. M., Amiri, F., Ahmad, N. B., Balasundram, M. A., \& Soom, M. A. M. (2013). Agriculture Land Suitability Evaluator (ALSE): A decision and planning support tool for tropical and subtropical crops. Computers and Electronics in Agriculture, 93(4), 98-110.

FAO. 1976. A Framework for land evaluation. FAO Soils Bulletin no 32. Food and Agriculture Organisation of the United Nations, Rome.

Han, W., Z. Yang, L. Di, Mueller, R. (2012). CropScape: A Web service based application for exploring and disseminating US conterminous geospatial cropland data products for decision support. Computers and Electronics in Agriculture, 84(6), 111-123.

Meensel, J.V., Lauwers, L., Kempen, I., Dessein, J., VanHuylenbroeck, G. (2012). Effect of a participatory approach on the successful development of agricultural decision support systems: The case of Pigs 2 win. Decision Support Systems, 54(1), 164-172.

Nurmiaty and Baja, S. 2014. Using Fuzzy Set Approaches in a Raster GIS for Land Suitability Assessment at a Regional Scale: Case Study in Maros Region, Indonesia. Modern Applied Science, 8(3),115-125. URL: https://doi.org/10.5539/mas.v8n3p115.

Ogie, R., Holderness, T., Dunbar, M., \& Turpin, E. (2016). Spatio-topological network analysis of hydrological infrastructure as a decision support tool for flood mitigation in coastal mega-cities. Environment and Planning B: Planning and Design. https://doi.org/10.1177/0265813516637608

Oliver, D. M., Fish, R. D., Winter, M., Hodgson, C. J., Heathwaite, A. L., Chadwick, D. R. (2012). Valuing local 
knowledge as a source of expert data: Farmer engagement and the design of decision support systems. Environmental Modelling \& Software, 36(10), 76-85.

RePPProT. (1988). The Land Resources of Indonesia: A National Overview Main Report. United Kingdom-ODA NRI. Ditjen Pankim, Department of Transmigration, Jakarta.

Sarkar, S., Dyer, J. S., Margules, C., Cierleglio, M., Kemp., N., Wong, G., Juhn, D., and Supriatna, J. (2016). Developing an objectives hierarchy for multicriteria decisions on land use options, with a case study of biodiversity conservation and forestry production from Papua, Indonesia. Environment and Planning B: Planning and Design. https://doi.org/10.1177/0265813516641684

Sugumaran, R. E. (2011). Spatial Decision Support System Principles and Practices. New York: CRC Press Taylor \& Francis Group.

USDA. (2006). Keys to Soil Taxonomy. Tenth Edition. Syst., 8: 369-376. The 18th World Congress of Soil Science. Philadeiphia, Pennsylvania, USA.

Walpole, S. C. (1998). Integration of economic and biophysical information to assess the site-specific profitability of land management programmes using a GIS. Pages 1663-1669, in: Proceedings of the $8^{\text {th }}$ ISCO Conference, New Delhi. International Soil Conservation Organisation and A.A. Balkema, Rotterdam.

\section{Copyrights}

Copyright for this article is retained by the author(s), with first publication rights granted to the journal.

This is an open-access article distributed under the terms and conditions of the Creative Commons Attribution license (http://creativecommons.org/licenses/by/4.0/). 